\title{
A microRNA network regulates proliferative timing and extracellular matrix synthesis during cellular quiescence in fibroblasts
}

Eric J Suh, Matthew Y Remillard, Aster Legesse-Miller, Elizabeth L Johnson, Johanna MS Lemons, Talia R Chapman, Joshua J Forman, Mina Kojima, Eric S Silberman and Hilary A Coller

\begin{abstract}
Background: Although quiescence (reversible cell cycle arrest) is a key part in the life history and fate of many mammalian cell types, the mechanisms of gene regulation in quiescent cells are poorly understood. We sought to clarify the role of microRNAs as regulators of the cellular functions of quiescent human fibroblasts.

Results: Using microarrays, we discovered that the expression of the majority of profiled microRNAs differed between proliferating and quiescent fibroblasts. Fibroblasts induced into quiescence by contact inhibition or serum starvation had similar microRNA profiles, indicating common changes induced by distinct quiescence signals. By analyzing the gene expression patterns of microRNA target genes with quiescence, we discovered a strong regulatory function for miR-29, which is downregulated with quiescence. Using microarrays and immunoblotting, we confirmed that miR-29 targets genes encoding collagen and other extracellular matrix proteins and that those target genes are induced in quiescence. In addition, overexpression of miR-29 resulted in more rapid cell cycle reentry from quiescence. We also found that let-7 and miR-125 were upregulated in quiescent cells. Overexpression of either one alone resulted in slower cell cycle re-entry from quiescence, while the combination of both together slowed cell cycle re-entry even further.
\end{abstract}

Conclusions: microRNAs regulate key aspects of fibroblast quiescence including the proliferative state of the cells as well as their gene expression profiles, in particular, the induction of extracellular matrix proteins in quiescent fibroblasts.

Keywords: MicroRNA, Quiescence, Cell cycle, Proliferation, Extracellular matrix, Fibroblast, Microarray, miR-29

\section{Background}

When mammalian cells are in an environment unfavorable for continued proliferation, they can exit the cell cycle in early to mid- $\mathrm{G}_{1}$ phase at the 'restriction point' [1] and enter a reversible, out-of-cell cycle state denoted 'quiescence'. Many cells in the human body are quiescent, and the ability of cells to exit the cell cycle but retain their capacity to re-enter the cell cycle as needed (for instance, when required to replenish a cell lineage, mount an immune response, or heal a wound) is central to normal physiology. Failures in this process may underlie a wide range of pathologies including excessive

\footnotetext{
*Correspondence: hcoller@princeton.edu

Princeton University, Department of Molecular Biology, 14 Washington Rd,
} Princeton, NJ 08544 USA scarring, fibrotic disease, chronic wounding, and cancer, yet we have a poor understanding of the changes that occur when cells become quiescent or the molecular basis for these changes.

Widespread gene expression changes occur when cells enter quiescence, including both repression and activation of genes [2-9]. These changes can vary among cell types and in response to different antiproliferative signals, but there are also commonalities in different types of quiescence and in different quiescent cell types [2,7-9]. Several important regulators of the gene expression changes that occur with quiescence have been described, including the $M Y C$ and $E 2 F$ family transcription factors that coordinate cell cycle re-entry and repress cell cycle genes during quiescence [5,10-13], and the HES1 transcriptional repressor 
that preserves the reversibility of quiescence [14]. There are also hundreds of genes that are upregulated when cells become quiescent, whose possible regulators include forkhead transcription factors [15,16], ELK1, NF- $\kappa B, M E F 2$, IRF, AP-1, SALL2, and MXI1 [5]. Despite these proposed factors, however, the drivers and mechanisms of many of the gene expression changes in quiescence are still not known.

In addition to regulation of quiescence by transcription factors, there is likely also regulation of quiescence gene expression changes at the post-transcriptional level. microRNAs are 20 to 23 nucleotide non-coding RNAs that regulate a wide variety of transcripts post-transcriptionally by inducing transcript degradation or inhibiting protein translation [17-19]. microRNAs have been implicated in a wide range of biological processes related to quiescence, including cell proliferation control, stem cell renewal, developmental timing, and cancer [20]. Medina and colleagues, for example, discovered that four microRNAs were upregulated and over 100 microRNAs were downregulated as T98G glioblastoma cells progress from quiescence into the proliferative cell cycle [21]. They and others demonstrated that miR-221 and miR-222 target the cyclin-dependent kinase inhibitors $\mathrm{p} 27^{\mathrm{Kip} 1}$ and $\mathrm{p} 57^{\mathrm{Kip} 2}$, such that overexpression of $m i R-221$ and $m i R-222$ during growth factor deprivation induces S-phase entry and triggers cell death [21-25].

Another example is the let-7 family of microRNAs, members of which are important regulators of cellular differentiation [26-34] and proliferation [29,35-37] in mammals, C. elegans, and Drosophila melanogaster. let-7 family members can behave as tumor suppressors and antagonize oncogenes such as MYC and RAS [28,35,38-45].

As a final example, the miR-17-92 cluster of six microRNAs, which is induced by the $M Y C$ oncogene [46], can itself act as an oncogene. Enforced expression of the miR17-92 cluster, in concert with MYC expression, can accelerate tumor development in a mouse B-cell lymphoma model [47]. While $M Y C$ can induce transcription of $E 2 F$ transcription factors, two of the members of the microRNA cluster, $m i R-17-5 p$ and $m i R-20 a$, negatively regulate levels of $E 2 F 1$, demonstrating a complex network of interactions that may affect the cell's commitment to proliferation or apoptosis [46-51].

We investigated the role of microRNAs in a fibroblast model of quiescence and discovered that microRNA expression is broadly and similarly altered by two different quiescence signals: contact inhibition and serum withdrawal. We further found that microRNAs regulate some of the changes in gene expression and cellular function associated with quiescence, as well as the transition between proliferation and quiescence.

\section{Results}

\section{microRNAs exhibit a strong quiescence signature}

We have developed a model system of quiescence in primary human fibroblasts in which quiescence can be induced by either serum starvation or contact inhibition. Either condition results in an accumulation of quiescent cells, as indicated by cell cycle markers and RNA content [52]. Using one-color microRNA microarrays, we monitored microRNA expression levels in proliferating, serumstarved, and contact-inhibited primary human dermal fibroblasts (Figure 1A). Among the 209 microRNAs detected above background, 142 (68\%) were expressed at different levels in proliferating compared with either serum-starved or contact-inhibited fibroblasts at a falsediscovery rate of $1 \%$ (Figure 1B). microRNA expression patterns for contact inhibition and serum starvation were extremely similar, with a $95 \%$ confidence interval (CI) Pearson's correlation of 0.952 to 0.975 , much more so than the mRNA expression patterns for the same conditions (Pearson's correlation of 0.319 to $0.341,95 \% \mathrm{CI}$ ) (Additional File 1, Figure S1). This large difference in the amount of correlation between quiescence states may be due to experimental design or microarray platform differences, but an alternative explanation is that microRNAs exhibit more of a common quiescence signature than protein-coding transcripts [2]. microRNAs downregulated in quiescent cells included $m i R-18, m i R-20, m i R-29$, and $m i R-7$, and microRNAs upregulated with quiescence included let-7b, miR-125a, miR-30, miR-181, miR-26, and miR-199. With a stringent cutoff of greater than two-fold expression change due to quiescence, eight microRNAs were expressed at higher levels in proliferating cells and eight were expressed at higher levels in quiescent cells (Additional File 1, Table S1).

We sought to validate the changes in microRNA levels with an independent method. In collaboration with Rosetta Inpharmatics, we used massively parallel, multiplexed qRT-PCR [53] to monitor the abundance of 219 microRNAs in fibroblasts collected during proliferation or after 4 days of serum starvation. There was strong agreement between the fold-change values obtained via the microarray and the multiplex qRT-PCR (Pearson's correlation 0.504 to $0.751,95 \% \mathrm{CI}$ ) (Additional File 1, Figure S2).

\section{Targets of microRNAs change with quiescence}

In order to identify microRNAs with a functional, regulatory role in quiescence, we analyzed the gene expression patterns of microRNA target genes in two whole-genome mRNA microarray timecourses comparing proliferating cells to cells induced into quiescence by contact inhibition or serum starvation (Figure 2A). In one timecourse, fibroblasts were made quiescent by serum withdrawal for 4 

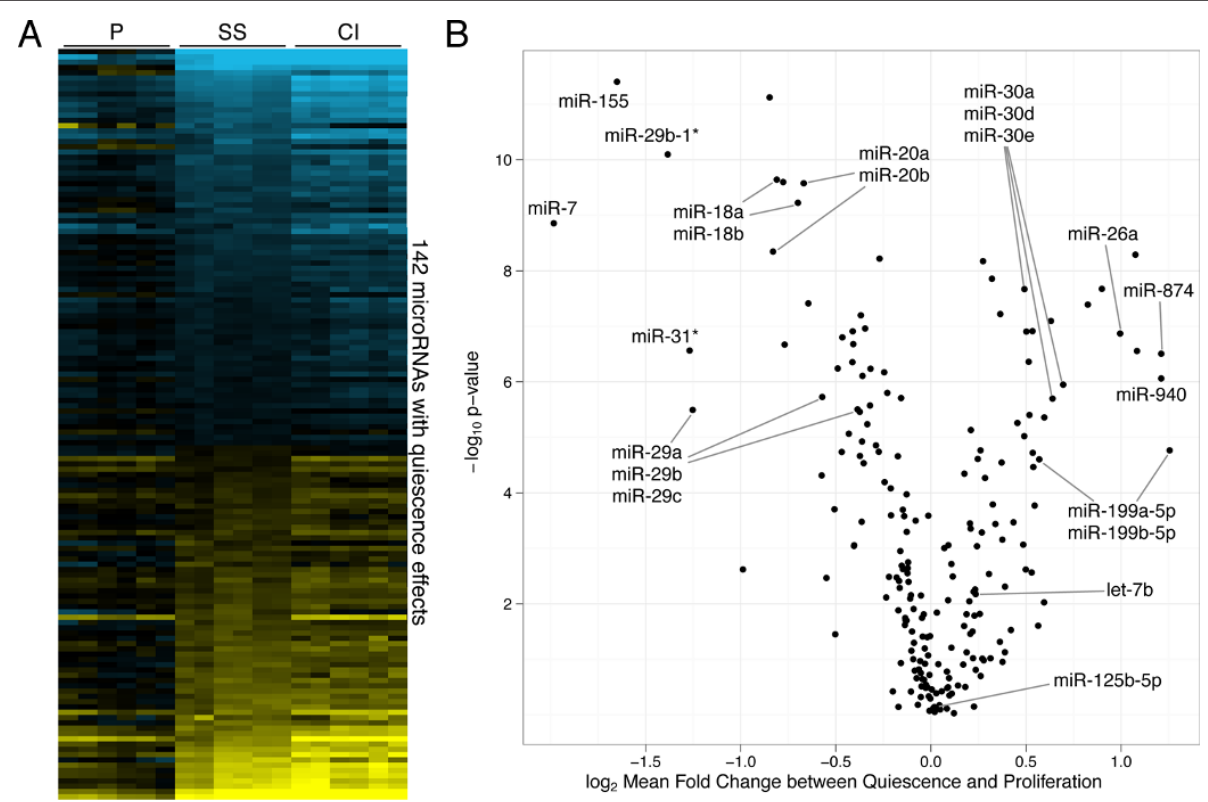

Figure 1 Widespread changes in microRNA abundance with quiescence. (A) The $\log _{2}$ fold-change in the expression of the 142 microRNAs that change expression at a 1\% FDR during serum starvation (SS) or contact inhibition (Cl) are depicted with respect to their average expression in proliferating $(P)$ cells. Blue and yellow indicate negative and positive values, respectively. Genes are in order of the magnitude of their mean $\log _{2}$ fold change from proliferation to quiescence. (B) 'Volcano' plot of microRNA average $\log _{2}$ fold-change in quiescence conditions on the $x$-axis versus the $\log _{10} P$ value for the significance of the quiescence parameter in gene expression on the $y$-axis.
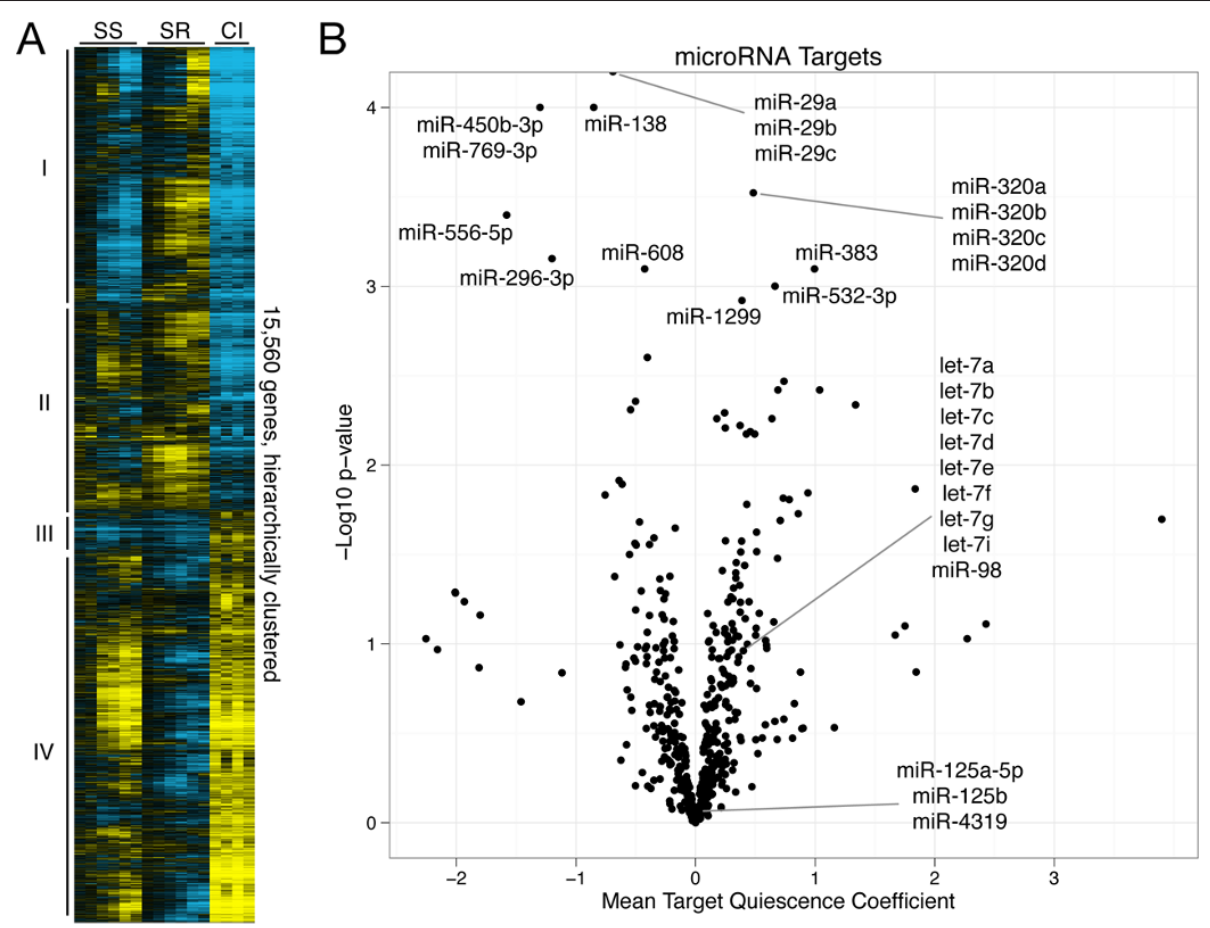

Figure 2 Changes in target genes with quiescence. (A) Hierarchical clustered heat map representing the $\log _{2}$ fold change of gene expression for all 15,560 consistently detectable genes during 1, 2, 4, 8, 24, and $96 \mathrm{~h}$ of serum starvation (SS), 1, 2, 4, 8, 24, and $48 \mathrm{~h}$ serum restimulation (SR), and 7 and 14 days (each repeated twice) of contact inhibition (Cl). Expression in serum starvation and contact inhibition is shown relative to proliferating cells, and expression during serum restimulation is shown relative to 4-day serum-starved cells. Colors are as in Figure 1A. Numerals designate 4 different clusters chosen from the hierarchical clustering tree. Select enriched gene ontology terms for each of the clusters are shown in Additional File 1, Table S2. (B) Volcano plot of the mean projection of the microRNA target genes' $\log _{2}$ expression onto the array's first eigengene (Additional File 1, Figure S3B) on the $x$-axis versus the $\log _{10} P$ value of the mean projection on the $y$-axis. 
days and then re-stimulated with serum for $48 \mathrm{~h}$ [54]. In another, fibroblasts were sampled after 7 or 14 days of contact inhibition [52]. Using singular value decomposition of the combined timecourses, we found that the strongest orthonormal gene expression pattern ('eigengene') correlated with the proliferative state of the cell (Additional File 1, Figure S3B). This eigengene explained approximately $40 \%$ of the gene expression variation (Additional File 1, Figure S3A). The linear projection of each gene to that eigengene gave a 'proliferation index' for each gene that summarized its association with proliferation or quiescence. For each microRNA, we averaged the proliferation indexes of its predicted target genes as provided by the TargetScan algorithm $[55,56]$ and assigned a $P$ value to that mean using bootstrap resampling (Figure 2B). The miR-29 family's targets had the most statistically extreme mean proliferation index, with a $P$ value $<10^{-4}$ (the lowest $P$ value possible based on the $10^{4}$ bootstrap resamplings taken). miR-29 expression is strongly associated with proliferation (Additional File 1, Figure S4), and its predicted targets are upregulated by both methods of quiescence induction.

Besides $m i R-29$, however, there were few microRNAs with strongly anti-correlated target genes. There are multiple possible explanations. First, expression levels and activity need not be completely correlated, as microRNA activity can be affected by the cooperation or antagonism of RNA-binding proteins [57-60] as well as changing mRNA abundance, dynamics, and primary and secondary structure [61-66]. Second, the microRNAs may be affecting translation rate but not transcript abundance, in which case their effects would not be detectable by microarray analysis. Finally, many of the microRNAs investigated likely regulate too few genes to be considered significant by this whole-genome target analysis, since a small list of targets can lead to artificially low statistical significance by bootstrap analysis. Indeed, some microRNAs might regulate a small number of critical genes and thereby produce an important functional effect even without a statistically significant change in the average proliferation index for all of its targets. For these reasons, we chose to investigate further $m i R-29$ and other candidates identified based on their previously reported associations with proliferation and cell cycle regulation: let-7 [35,36] and miR-125 [32,33].

\section{miR-29 regulates collagen and collagen-chaperone genes} Gene ontology analysis of predicted, evolutionarily conserved $m i R-29$ targets revealed an enrichment for multiple categories including collagen fibril organization and extracellular matrix formation (Additional File 1, Table S3), indicating that $m i R-29$ most likely regulates extracellular matrix (ECM) biosynthesis in fibroblasts, consistent with previous reports on $m i R-29$ in fibroblasts and other cell types [67-72]. We identified $m i R-29$ targets in dermal fibroblasts by overexpressing $m i R-29$ in asynchronously proliferating fibroblasts and analyzing the ensuing changes in gene expression by microarray analysis. As expected, genes predicted to be $m i R-29$ targets by TargetScan were more likely to be repressed by $m i R-29$ overexpression than genes not predicted to be $m i R-29$ targets (Figure 3B). We identified genes that both changed significantly in the microarray analysis and contained predicted $m i R-29$ binding sites. Of the 15 genes that met these criteria, nine are involved in extracellular matrix formation (Figure 3A and Table 1). When we plotted the behavior of these same genes in the serum starvation and contact inhibition microarray timecourse data, we discovered that these genes display a quiescence-associated gene expression pattern. The genes encoding $m i R-29$ targets followed a general pattern of increasing expression as fibroblasts are serum-starved, decreasing expression as they are restimulated, and highest expression in cells that were contactinhibited for 7 or 14 days (Figure 3C). These genes were therefore highly anti-correlated with the pattern of expression for $m i R-29$ itself (Additional File 1, Figure S4). These results suggest that the downregulation of $m i R-29$ expression levels in quiescent fibroblasts is an important contributor to the induction of extracellular matrix genes with quiescence.

We sought to confirm whether miR-29 regulates not just transcript abundance, but also protein levels of extracellular matrix components in quiescent cells. We investigated three proteins encoded by miR-29 targets (collagen I, collagen III, and collagen VI) by immunoblot analysis of protein lysates isolated from proliferating cells and cells made quiescent by mitogen (PDGF) withdrawal or contact inhibition. As anticipated, all three proteins were upregulated in both quiescence conditions compared with proliferating cells. These three $m i R-29$ targets were also strongly repressed at the protein level by transfection of $m i R-29$ as compared to transfection of a negative control, non-targeting microRNA, while protein levels of GAPDH and $\alpha$ tubulin (two proteins from genes not targeted by $m i R-29$ ) were unaffected (Figure 3D).

\section{Autocrine TGF- $ß$ is unlikely to mediate $m i R-29$ expression changes in quiescence}

TGF- $\beta$ signaling leads to an increase in collagen synthesis [73] and can repress miR-29 [69,74,75]. We confirmed that exogenous addition of TGF- $\beta$ repressed $m i R-29$ expression, as measured by qRT-PCR (Additional File 1, Figure S5A), in our dermal fibroblast model. Although exogenous TGF- $\beta$ can downregulate $m i R-29$, immunoblots for Smad3 phosphorylation levels showed no significant difference in autocrine TGF- $\beta$ signaling between proliferating and quiescent fibroblasts (Additional File 1, Figure S5B), indicating that the TGF- $B$ signaling pathway is unlikely to be responsible for the reduction in $m i R-29$ 
A
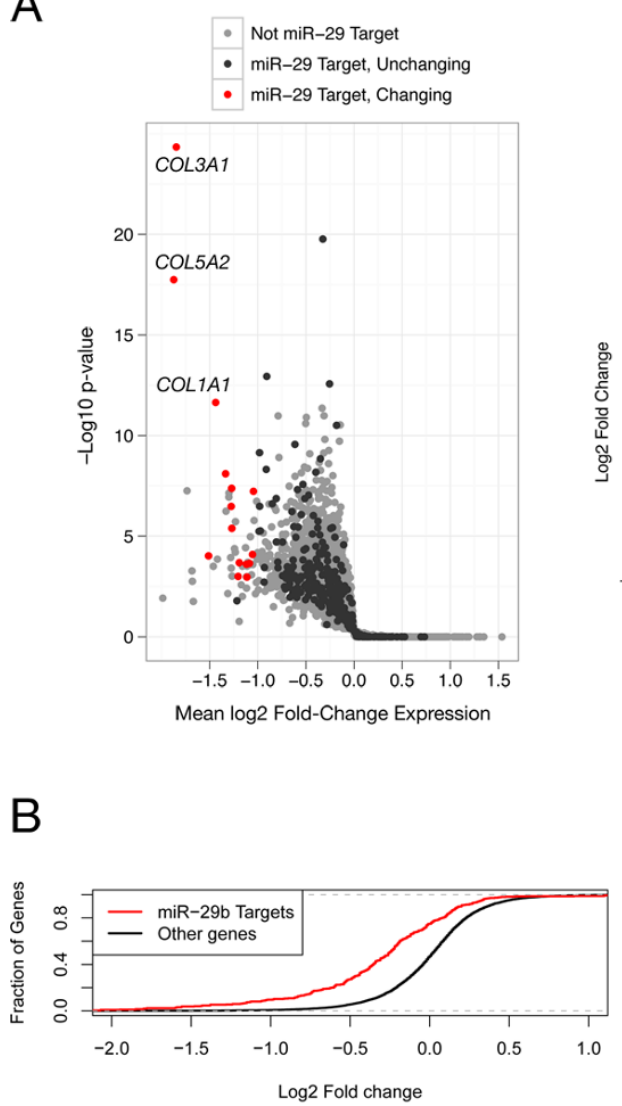
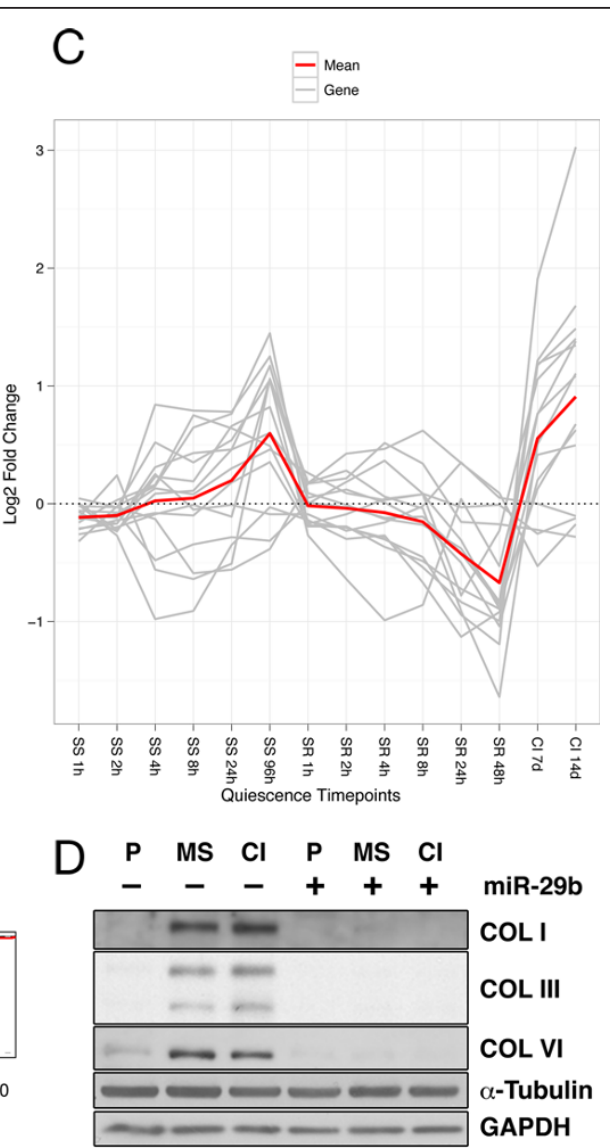

Figure 3 miR-29 repression of extracellular matrix protein production with quiescence. (A) Gene expression changes induced $48 \mathrm{~h}$ after miR-29 transfection into fibroblasts. The $x$-axis denotes the mean $\log _{2}$ fold change in expression compared to negative control, and the $y$-axis denotes $-\log _{10}$ of the $P$ value of a one-sided $t$-test. (B) Empirical cumulative distribution function of $\log _{2}$ fold-changes induced by miR-29 transfection, comparing predicted targets to all other non-target genes. (C) Quiescence microarray expression timecourses (Figure 2A) of each miR-29 target in Table 1 (shown in gray), along with the mean $\log _{2}$ fold change at each timepoint (shown in red). (D) Protein expression, as determined by immunoblotting, of selected miR-29 targets in proliferating (P), mitogen-starved (MS), or contact inhibited (CI) states with transfection of a negative control microRNA or miR-29. Collagen III here appears as a doublet corresponding to its two isomers. Immunoblots to GAPDH and $\alpha$-Tubulin are shown as examples of genes not targeted by miR-29 and as loading controls.

expression in quiescent fibroblasts. In addition, although TGF- $ß$ can regulate collagen expression independently of miR-29 [76,77], the similar phospho-Smad3 levels in proliferating and quiescent fibroblasts implies that changes in TGF- $\beta$ activity are unlikely to significantly regulate collagen biosynthesis in quiescence, further emphasizing the importance of $m i R-29$ as a regulator of quiescenceassociated changes in ECM expression.

\section{miR-29 hastens cell cycle re-entry from quiescence}

We also tested whether $m i R-29$ has a role in the cell cycle transition between proliferation and quiescence by simultaneously restimulating serum-starved fibroblasts to proliferate with full serum medium and transfecting them with $m i R-29$. Over the next $36 \mathrm{~h}$, we quantified by flow cytometry the rate of EdU nucleotide analogue incorporation by the cells and their overall DNA content, which allowed us to assign cells to $G_{0} / G_{1}, S$, and $G_{2} / M$ phases of the cell cycle [78]. When compared to cells transfected with a control non-targeting microRNA, cells transfected with miR-29 contained fewer cells in $\mathrm{G}_{0} / \mathrm{G}_{1}$ and more cells in $S$ phase at 20 and 24 h post transfection (Figure 4A, $P=1.9 \times 10^{-7}, 3.0 \times 10^{-11}$ for 20 and $24 \mathrm{~h}$ timepoints, respectively). At 28 and $32 \mathrm{~h}$ after transfection, cells transfected with $m i R-29$ contained fewer cells in $S$ phase and more cells in $G_{2} / M$ phase than those transfected with the control ( $P=0.012$ for $28 \mathrm{~h}$ timepoint). miR-29 overexpression thus hastens re-entry into the cell cycle from a quiescent state.

To further explore the effects of $m i R-29$ expression on the cell cycle, we transfected miR-29 or a negative control microRNA into asynchronously cycling fibroblasts. Fortyeight hours post transfection, $m i R-29$ transfection led to more cells in $\mathrm{G}_{2} / \mathrm{M}$ (Figure $4 \mathrm{~B}$ ). As expected considering 
Table 1 miR-29 experimentally-determined targets.

\begin{tabular}{lll}
\hline Gene & Log $_{\mathbf{2}}$ fold change & Function \\
\hline ARRDC4 & -1.19 & N/A \\
\hline BLMH & -1.05 & N/A \\
\hline CDK6 & -1.27 & Cell cycle \\
\hline COL1A1 & -1.44 & ECM \\
\hline COL3A1 & -1.85 & ECM \\
\hline COL5A2 & -1.87 & ECM \\
\hline FBN1 & -1.27 & ECM \\
\hline FSTL1 & -1.51 & BMP antag. \\
\hline LAMC1 & -1.06 & ECM \\
\hline MFAP2 & -1.11 & ECM \\
\hline PPIC & -1.28 & ECM? \\
\hline RCC2 & -1.21 & Cell cycle \\
\hline SERPINH1 & -1.09 & ECM \\
\hline SPARC & -1.34 & ECM \\
\hline TBC1D7 & -1.12 & N/A \\
\hline
\end{tabular}

Genes listed were significantly repressed by miR-29 transfection according to a one-sided $t$-test at $5 \%$ FDR, had $\log _{2}$ fold changes of $<-1.0$, and are evolutionarily conserved miR-29 targets as annotated by TargetScan.

that cells in the G2/M phase tend to be larger than cells in other phases of the cell cycle, $m i R-29$ transfection also led to larger cells (Figure 4D). Further experimentation revealed that $m i R-29$ transfection resulted in fewer cells than the negative control transfection (Figure $4 \mathrm{C}$, $P=0.025)$. Thus, $m i R-29$ transfection in proliferating cells led to $G_{2} / M$ arrest rather than increased mitosis. This may reflect the activity of a $m i R-29$ target gene; indeed, one target, $R C C 2$ (TD-60), is repressed about $57 \%$ upon $m i R-29$ transfection (Figure $3 \mathrm{~A}$ and Table 1), and it plays an essential role in progression through metaphase [79].

\section{let-7 and miR-125 non-redundantly delay cell cycle entry} from quiescence

let-7 plays roles in differentiation, cancer, and the cell cycle, as discussed above. In C. elegens, the lin-4 microRNA (miR-125 in mammals) acts in the same heterochronic pathway of temporal differentiation as let-7 [27]. The two microRNAs are also frequently located together in microRNA clusters across many phylogenetic lineages [80]. In multiple species, they are co-regulated and share partly overlapping roles during development [81-86]. Because both let-7 and miR-125 are upregulated in quiescence, we investigated whether let-7 and miR-125 have complementary roles in cell cycle regulation.

We monitored the functional roles of let-7 and $m i R-125$ on cell cycle re-entry from quiescence using the same method we used for $m i R-29$ as described above. Compared with control-transfected cells, cells transfected with let-7 contained an elevated fraction of cells in the $G_{0} / G_{1}$ phase at 20 and 24 h post transfection and fewer cells in $S$ phase at $20 \mathrm{~h}$ post transfection (Figure $4 \mathrm{~A}, P=0.0042,0.0083$ for 20 and $24 \mathrm{~h}$ timepoints, respectively), indicating that cell cycle re-entry is delayed by let- 7 overexpression. By 32 $\mathrm{h}$ post transfection, the let-7-overexpressing population contained more cells in the $\mathrm{G}_{2} / \mathrm{M}$ phase than control cells $(P=0.0013)$, as we have previously reported [36]. We observed an even stronger effect on cell cycle re-entry with miR-125 than for let-7. At 20 and $24 \mathrm{~h}$ after transfection, cells transfected with $m i R-125$ contained more cells in $G_{0} / G_{1}$ and fewer cells in $S$ phase than controls (Figure $4 \mathrm{~A}, P=7.5 \times 10^{-6}, 6.0 \times 10^{-9}$ for 20 and $24 \mathrm{~h}$ timepoints, respectively). To assess whether let-7 and $m i R-125$ have complementary effects on cell cycle progression, we overexpressed a combination of the two microRNAs. Overexpression of let-7 and $m i R-125$ together resulted in a further accumulation of cells in $G_{0} / G_{1}$ and even slower $\mathrm{S}$ phase entry than either individually (Figure 4A, $P=1.0 \times 10^{-8}, 1.0 \times 10^{-4}$ compared to let- 7 and miR-125, respectively, at the $20 \mathrm{~h}$ timepoint), implying that their cell cycle effects are non-redundant and complementary.

\section{Discussion}

\section{A microRNA quiescence program}

While the predominant view of quiescent cells is that they are inactive or 'shut down', our data from several different lines of experimentation indicate that the transition into quiescence in fibroblasts is a highly regulated and active process $[2,14,52]$. We previously reported [2], and we again confirmed by our SVD analysis of quiescence gene expression timecourse data (Figure 2), that entry into quiescence in fibroblasts is associated with large-scale remodeling of gene expression patterns affecting a significant fraction of all genes within the genome, with comparable numbers of genes both increasing and decreasing in expression. We show here that entry into quiescence is also associated with widespread changes in the abundance of a significant number of microRNAs. microRNAs both increase and decrease in abundance upon entry into quiescence, similar to the effects on mRNA expression.

One clear distinction between microRNAs and mRNAs was noticed: while gene expression patterns have both a common component and a signal-specific component [2] (Figure 2A), microRNA patterns with quiescence were very similar for samples made quiescent by two distinct quiescence signals (contact inhibition and serum starvation). This finding is in accord with previous studies that indicated that microRNA profiles are extremely informative about a human cancer's developmental lineage and differentiation state, and that microRNAs are particularly valuable for classifying 


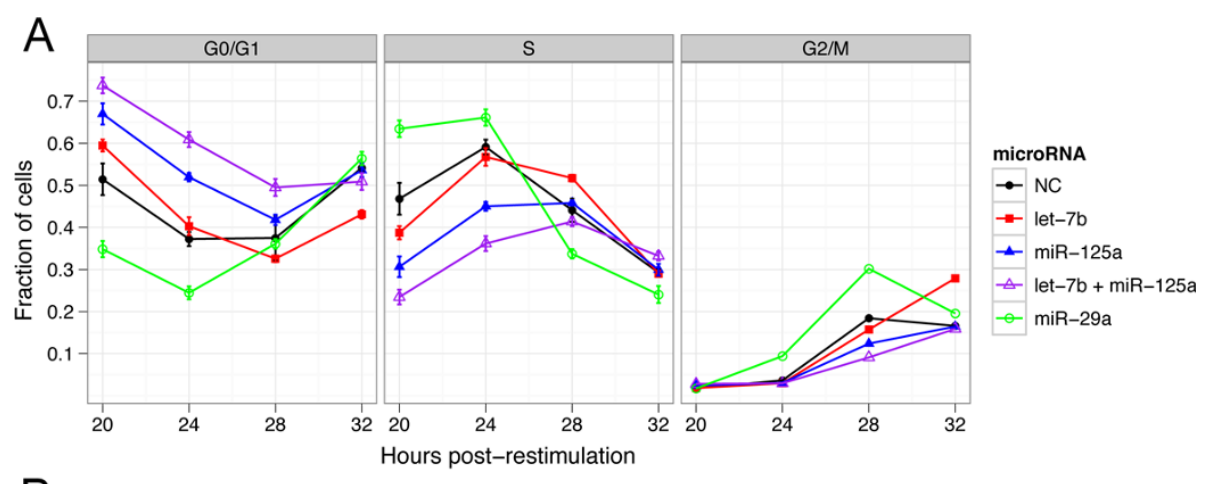

B
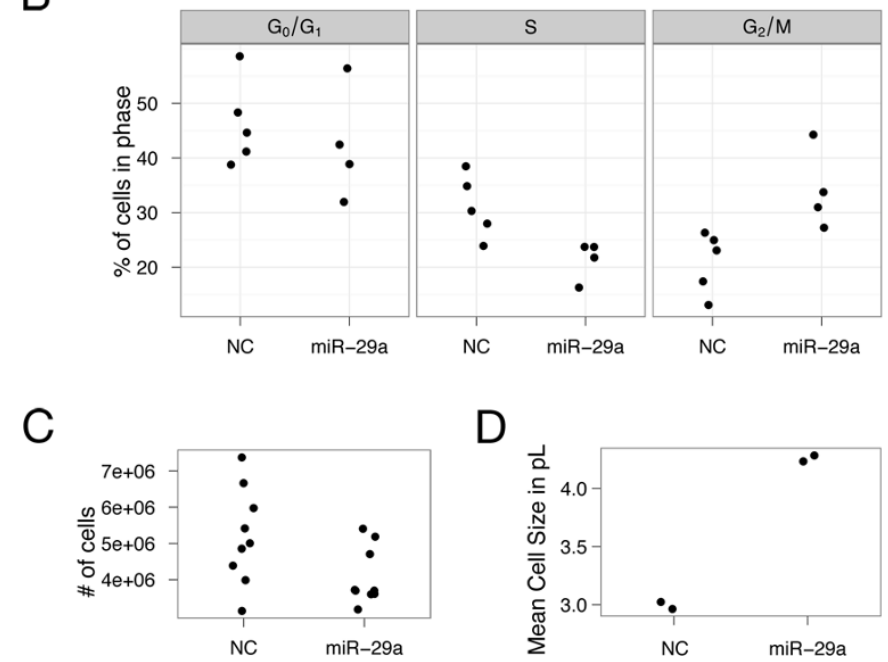

Figure 4 Cell cycle and cell size effects of microRNAs let-7, miR-125, and miR-29. (A) Cell cycle progression of serum-restimulated quiescent cells with simultaneous transfection of miR-29, let-7, miR-125, a combination of let-7 and miR-125, or a negative control (NC) non-targeting miRNA. The fraction of cells in different cell cycle phases is plotted with error bars of the residual sums of squares from two timecourses measured in triplicate. (B) Cell cycle phase distribution of asynchronously proliferating fibroblasts $48 \mathrm{~h}$ after transfection with miR-29. (C) Cell numbers $48 \mathrm{~h}$ after miR-29 transfection. (D) Cell sizes $48 \mathrm{~h}$ after miR-29 transfection.

poorly differentiated tumors $[87,88]$. Indeed, our data suggest that there may be a quiescence microRNA program that is stronger and more consistent than a quiescence gene expression program. Such a signature may facilitate the identification of universal quiescencerelated pathways.

\section{The complementarity of let-7 and miR-125}

In many organisms, lin-4 (miR-125) and let-7 are both important for developmental programs involving differentiation or cell cycle arrest [26,31]. Low levels of let-7, for example, are associated with pluripotency and proliferation, while higher let-7 levels are associated with cell cycle exit and differentiation $[28,34,89]$. In vertebrates, mature let-7 and $m i R-125$ are largely absent from early embryos and are induced upon differentiation [84-86]. We previously reported that let-7 targets the E2 ubiquitin ligase CDC34 and that let-7 overexpression in fibroblasts results in a $\mathrm{G}_{2} / \mathrm{M}$ arrest [36]. Here we show that, when overexpressed, both $m i R-125$ and let-7 specifically affect the ability of quiescent fibroblasts to re-enter the proliferative cell cycle from quiescence induced by serum starvation.

Our data and the literature, taken together, support a model in which $m i R-125$ and let-7 family members are induced upon the commitment to a cell state lineage or reversible cell cycle exit. During differentiation or quiescence, let-7 and miR-125 may actively suppress the expression of cell cycle-associated transcripts through a post-transcriptional mechanism that reinforces the out-ofcycle state established by transcriptional mechanisms. Possible candidates for these transcripts include previously reported cell cycle targets of let-7 such as RAS [39], CCND1 [90], CDC25 [35], and CDC34 [36], and miR-125 targets such as BCL3 [91] and ETS1 [92]. Our results indicate that in reversibly arrested cells, miR-125 and let-7 downregulate cell proliferation-promoting genes. Upon restimulation, these genes are released from let-7 and miR-125-mediated repression and are required for normal cell cycle re-entry. 
Although miR-125 and let-7 are co-conserved and coregulated in many organisms, the two microRNAs also share some overlapping target genes [33,93,94], which suggests the possibility that some of the functional effects on the cell cycle exerted by each microRNA are redundant. Our results demonstrate that introduction of both microRNAs together had a stronger effect on cell cycle re-entry than introduction of either one alone, suggesting that they cooperate and play non-redundant roles in suppressing the expression of proliferation-associated genes in quiescent cells. This finding helps to explain the strong evolutionary selection to retain both microRNAs. Exogenous delivery of the let-7 microRNA has been shown to cause regression of murine lung tumors through an effect on cell proliferation distinct from apoptosis [45]. Our data indicate that administration of $m i R-125$ or a combination of let-7 and miR-125 might have even greater effects.

\section{miR-29's role in quiescence}

One of the functional changes that we previously observed in quiescent fibroblasts is an overall induction of extracellular matrix proteins [52]. We report here that downregulation of the microRNA miR-29 is likely regulating the induction of extracellular matrix protein expression with quiescence: as $m i R-29$ levels decline with quiescence, levels of $m i R-29$ targets increase, and miR-29 overexpression represses the levels of these targets. Reporter assays by multiple independent groups have found in several different cell types that miR-29 directly targets collagens COL1A1, COL3A1, and COL4A2 in a seed sequencedependent manner [95-97]. Based on those studies and our microarray and immunoblot results, $m i R-29$ likely also represses collagens directly in proliferating fibroblasts. The findings place $m i R-29$ among the very few molecules discovered, along with FoxO [98-100], and FoxP [101,102] transcription factors, and the regulators of miR-29 itself, to regulate the induction (as opposed to the repression) of genes in quiescent cells. Because our data indicate that the activity of the TGF- $\beta$ signaling pathway is similar in proliferating and quiescent fibroblasts, it is not likely that TGF$B$ is regulating the changes in miR-29 expression between these states. Other possible candidates for $m i R-29$ transcriptional regulation include NF- $\kappa \mathrm{B}$ and sonic hedgehog $[70,103]$. Further study is necessary to elucidate which factors are responsible in quiescence.

Repression of $R C C 2$ could explain the $\mathrm{G}_{2} / \mathrm{M}$ arrest phenotype seen with miR-29 transfection. Targets identified in other model systems could also be relevant. miR-29 targeting of DNA methyltransferases 3A and 3B, for example, can inhibit lung cancer cell tumorigenicity [104]. miR-29 can also induce apoptosis in cholangiocarcioma cells via the $m i R-29$ target $M C L-1$ [105], and induce replicative senescence in HeLa cells by targeting $B-M Y B$ [106].
We suggest that the role of $m i R-29$ in hastening cell cycle re-entry, however, may reflect its effects not on validated cell cycle regulators, but instead on extracellular matrix proteins. Quiescent cells, in general, are relieved of the biosynthetic requirement of synthesizing the constituents of new cells, but in our fibroblast model system they also retain a comparable rate of metabolic activity as proliferating fibroblasts [52]. Indeed, we discovered that fibroblasts express increased levels of several extracellular matrix proteins during quiescence compared with proliferation [52] (Figures 3C and 3D). From this perspective, it is particularly interesting that $m i R-29$ overexpression results in more rapid cell cycle entry. Although miR-29 has been reported to be an oncogene (transgenic mice overexpressing $m i R-29$ in their B cells develop B-cell chronic lymphocytic leukemia [107]) our microarray data revealed no clear candidate cell cycle genes that would explain the early re-entry phenotype we observed in our model system.

We suggest an alternative possibility: relieved of the commitment to translate and fold extracellular matrix proteins like collagen, $m i R$-29-overexpressing cells may be able to commit more rapidly to the cell cycle. If a competition exists for translational resources between the synthesis of proteins required for cell duplication and the synthesis of proteins targeted for secretory pathways, then miR-29 may be able to direct resources between those two processes depending on the proliferative state of the cell. Further studies, especially on fibroblast cell lines derived from patients with idiopathic pulmonary fibrosis, which are characterized by excessive secretion of extracellular matrix proteins $[108,109]$, will be able to elucidate whether $m i R-29$ is an important regulator of a tradeoff between proliferative and secretory modes.

\section{Conclusions}

Our data indicate that quiescence is associated with widespread, consistent changes in microRNA abundance. The regulated microRNAs contribute to gene expression programs that form the characteristic attributes of quiescent cells by reinforcing the non-proliferative nature of the cells and also regulating their cell-type specific roles. As such, further investigation into microRNAs should lead to a greater understanding of both universal aspects of quiescence programs as well as the regulation of processes specific to a quiescent cell's in vivo roles. Our results support some of the ongoing efforts to administer microRNAs to patients of cancer and fibrotic disease and suggest some new strategies.

\section{Materials and methods \\ Cell culture}

We isolated primary fibroblasts from neonatal human foreskin tissue samples provided by the National Disease 
Research Interchange (NDRI) as described in the supplementary methods for Legesse-Miller et al. [36] We routinely cultured the fibroblasts aseptically at $37^{\circ} \mathrm{C}$ with $5 \%$ $\mathrm{CO}_{2}$ in high-glucose DMEM with $4.5 \mathrm{mM}$ glutamine (Life Technologies) supplemented with $10 \%(\mathrm{v} / \mathrm{v})$ fetal bovine serum (FBS) (Hyclone) and $100 \mu \mathrm{g} / \mathrm{mL}$ penicillin and streptomycin (Life Technologies). Cells were serumstarved by reducing the serum concentration to $0.1 \%(\mathrm{v} / \mathrm{v})$. To generate contact-inhibited samples, we plated fibroblasts and changed their culture medium regularly (every 2 or 3 days) without passaging them.

\section{microRNA microarrays}

Three isolates of dermal fibroblasts were harvested in proliferative conditions, that is, sparsely subcultured 2 days before harvest, after 4 days of serum starvation, or after 7 days of contact inhibition. Cells were harvested by trypsinization, centrifuged at $160 \times g$, and snap-frozen in liquid nitrogen. Total RNA was isolated from the frozen cells using the mirVana miRNA isolation kit (Life Technologies). RNA quality was confirmed using a Bioanalyzer 2100 (Agilent Technology) and the concentration was determined with a NanoDrop spectrophotometer (NanoDrop Technologies). 100 ng of each sample was 3'-labeled with $\mathrm{Cy} 3-\mathrm{pCp}$ in two separate reactions and hybridized to microarray slides using the Agilent microRNA microarray kit (Agilent, G4470A). Microarray features were extracted with Feature Extractor 9.5.3.1. We normalized arrays for total intensity and then regressed each gene's expression using the model

$$
Y_{i}=m_{i}+B_{i, Q} x_{Q}+B_{i, s} x_{s}+B_{i, c_{1}} x_{c_{1}}+B_{i, c_{2}} x_{c_{2}}+B_{i, \mathrm{SVA}} x_{\mathrm{SVA}}+E_{i, Q, s, c_{1}, c_{2}, \mathrm{SVA}},
$$

where $i$ denotes the index for a microRNA, $Q, S, C_{1}$, and $C_{2}$ are annotations for quiescence, serum starvation, and the different fibroblast cell isolates, respectively, and $S V A$ denotes the one significant surrogate variable we found as described below. $Y_{i}$ is the measured $\log _{2}$ expression for microRNA $i$ and $m_{i}$ is its baseline expression. The $x$ variables are the given experimental variables (indexed by subscripts) with values 0 or 1 , the $B$ coefficients are the gene-specific responses to a particular $x$ variable, and $E$ is the error term. Surrogate variable analysis (SVA) was performed with the R package from Leek et al. [110], giving the one significant surrogate variable we included in the multiple regression analysis. Differential expression due to quiescence was determined with an $F$-test for the significance of the microRNA's response to variable $x_{Q}$, with a false-discovery rate of $1 \%$ deemed statistically significant. microRNAs without statistically significant gene expression change from quiescence were not shown in Figure 1A and 1B.

We denoted the overall biological response to serum starvation and contact inhibition (plotted $\log _{2}$ transformed in both Figure 1A as the heat-map intensities and Figure $1 \mathrm{~B}$ along the $x$-axis) as the sum of the responses $B_{i, Q}, B_{i, S}$ and the residuals $E_{i, Q, S_{1} C_{1}, C_{2}, S V A}$. The Pearson correlation coefficient was calculated comparing these values in the serum starvation and contact inhibition conditions.

\section{Multiplexed real-time PCR for microRNA expression levels}

We collected primary human fibroblasts over a timecourse during serum starvation. Copy number of each microRNA per $10 \mathrm{pg}$ of total RNA was determined using the protocol described in [53]. In summary, RNA was extracted using the mirVana microRNA isolation kit as described above, and a tailed, gene-specific primer was used to convert the RNA template into cDNA with a universal PCR binding site at one end. The resulting primer-extended, full-length cDNA was amplified in a highly multiplexed manner for 219 individual microRNAs. Real-time PCR was performed with a combination of an LNA-containing microRNA/ siRNA-specific 'reverse' primer and a generic universal primer complementary to the universal binding site introduced during reverse transcription. Amplification was monitored with SYBR green fluorescence. The cycle number at which the signal exceeded the background was used to determine the absolute abundance of the monitored microRNA in the sample. The Pearson's correlation between the real-time PCR data and the microRNA microarray data was determined between the 4-day serum-starved data point for the qRT-PCR and the mean of the $B_{i, S}$ serum starvation responses from the multiple regression for the microarray.

\section{Gene expression microarrays for quiescence and mir-29 targets}

Contact-inhibited fibroblast gene expression microarrays and serum starvation and restimulation arrays have been previous described $[52,54]$. To summarize briefly, total RNA was isolated from proliferating, serum-starved, and serum-stimulated fibroblasts as described above for the microRNA microarray. Total RNA from each sample, 325 ng each, was amplified and labeled using the Low RNA Input Fluorescent Labeling Kit (Agilent Technologies) to incorporate Cyanine 3-CTP (Cy-3) or Cyanine 5-CTP (Cy-5). Cy-3-labeled time zero samples were used as a reference for serum withdrawal samples, which were labeled with Cyanine 5-CTP. For serum stimulation, 4-day serum-starved fibroblasts were labeled with $\mathrm{Cy}-3$ and stimulated samples were labeled with Cy-5. Labeled cRNA was mixed and co-hybridized to whole Human Genome Oligo Microarray slides (Agilent Technologies) at $60^{\circ} \mathrm{C}$ for $17 \mathrm{~h}$ and subsequently washed with the Agilent Oligo Microarray Hybridization Kit. Slides were scanned with a dual laser scanner (Agilent Technologies). The Agilent feature extraction software, in conjunction with the Princeton 
University Microarray database, was used to compute the log ratio of the difference between the two samples for each gene after background subtraction and dye normalization. Of the approximately 44,000 probes on the microarray, probes that generated signal in at least $80 \%$ of arrays were identified. Fluorescence data for each probe were mapped to genes based on UniGene Clusters. If multiple probes mapped to a single gene, the values were averaged. The Pearson correlation coefficient was computed between the $96 \mathrm{~h}$ serum-starved sample and the mean of the $7 \mathrm{~d}$ contact-inhibited samples. Hierarchical clustering was performed on centered genes via centroid linkage, and four clusters were chosen based on the resulting dendrogram. Gene ontology (GO) term enrichment was determined using the Generic Gene Ontology Term Finder [111]. Qualitatively non-informative or redundant GO terms (for example, 'Biological process' or 'cell cycle' vs. 'cell cycle process') were removed to give a selected subset.

For $m i R-29$ overexpression microarrays, fibroblasts were transfected as described below with Pre-miR miR$29 b$ or Negative Control \#2 oligonucleotide duplexes (Life Technologies). Forty-eight hours after transfection, total RNA from the cells was harvested and hybridized to microarrays as above. The experiments were repeated on three different dermal fibroblast isolates. Target genes annotated by TargetScan $5.1[55,56,112]$ were considered well-conserved miR-29 targets if $\mathrm{P}_{\mathrm{CT}}>0.5$. A one-sided $t$-test was used to calculate the significance of the $\log _{2}$ fold change between the miR-29b transfection and the control, and a gene was declared 'changing' if it was repressed greater than two-fold at 5\% FDR.

\section{Singular value decomposition to identify microRNAs with significantly changing predicted targets}

The matrix of gene expression arrays was filtered to exclude genes with missing values in any array, and this matrix was decomposed by singular value decomposition (SVD) to obtain 16 eigengenes. Each gene's expression profile was then linearly projected onto the first eigengene to obtain one summarizing number, dubbed the 'proliferation index', as genes with a strong positive projection tend to be associated with proliferation and genes with a strong negative projection tend to be associated with quiescence. Sets of computationally-predicted target genes were obtained from TargetScan by excluding all predictions with context scores $>-0.5$ (negative numbers indicate more confident predictions). The mean projection of each of these target gene sets and its additive inverse were used as two-tailed test statistics on a null hypothesis distribution of 10,000 mean projections of randomly sampled gene sets. Each sample gene set was the same size as the original target gene set for which the linear projection was calculated.

\section{Overexpression of microRNA mimics}

Proliferating or 4-day serum-starved primary fibroblasts were reverse-transfected using Oligofectamine (Life Technologies) with a $50 \mathrm{nM}$ final concentration of Pre-miR microRNA duplexes let-7b, miR-125a, miR-29a, a 1:1 combination of let-7b and miR-125a, or the Negative Control \#2 non-targeting control (Life Technologies). The microRNA duplexes and Oligofectamine were diluted in OptiMEM I (Life Technologies) and incubated at room temperature for $15 \mathrm{~min}$. Human fibroblasts were trypsinized, washed, and then re-suspended in OptiMEM I at a concentration of 375,000 cells $/ \mathrm{mL}$. One milliliter of the transfection mixture was added to $4 \mathrm{~mL}$ of the cell suspension and plated on a $10 \mathrm{~cm}$ plate. The cells were incubated for $4 \mathrm{~h}$ and then supplemented with $5 \mathrm{~mL}$ of DMEM with $20 \%$ FBS. Twenty-four hours post transfection the medium was changed to DMEM containing 10\% FBS.

For the serum-restimulation timecourses, we measured the duration of serum restimulation from the moment at which DMEM with 20\% FBS was added. These experiments were done in triplicate on two different days (six timecourses in total). Standard error was calculated for both $G_{0} / G_{1}$ and $S$ phase percentages at each timepoint as the square root of the total sum of square residuals from the mean percentage on each day. Proliferating cells were harvested $48 \mathrm{~h}$ after transfection for the assays described below.

\section{Cell cycle progression assay}

We determined cell cycle phases using Click-iT EdU Alexa Fluor 488 according to the protocol in [78]. Briefly, we added $10 \mu \mathrm{L}$ of a $10 \mathrm{mM}$ EdU solution (Life Technologies) in phosphate-buffered saline (PBS) (Life Technologies) directly to $10 \mathrm{~mL}$ of culture medium on fibroblasts for a final concentration of $10 \mu \mathrm{M}$. We incubated the cells for $2 \mathrm{~h}$ with the EdU, and then trypsinized and re-suspended them to $1 \times 10^{7}$ cells $/ \mathrm{mL}$ in PBS containing $1 \%$ bovine serum albumin (BSA) (Amresco). A total of $100 \mu \mathrm{L}$ of this cell suspension was added to $100 \mu \mathrm{L}$ of freshly prepared $4 \%$ formaldehyde in PBS (Thermo Scientific) and incubated in the dark at room temperature for $15 \mathrm{~min}$. Three milliliters of PBS with $1 \%$ BSA was added to quench the fixation. The cells were then resuspended in $100 \mu \mathrm{L}$ of PBS containing 1\% BSA and added to $100 \mu \mathrm{L}$ of $0.2 \%$ Triton X-100 in PBS. We added to each sample $500 \mu \mathrm{L}$ of Click-iT reaction cocktail: $100 \mathrm{mM}$ Tris-Cl, $\mathrm{pH}$ 8.5, $2 \mathrm{mM}$ $\mathrm{CuSO}_{4}, 10 \mu \mathrm{M}$ Alexa Fluor 488 azide (Life Technologies), and $100 \mathrm{mM}$ ascorbic acid. The mixture was incubated in the dark at room temperature for $30 \mathrm{~min}$. Two milliliters of wash buffer (1\% BSA, $0.2 \%$ Triton X-100 in PBS) was added, the cells were pelleted at $200 \times \mathrm{g}$ for $5 \mathrm{~min}$, and the supernatant was discarded. We then resuspended the labeled cells in $500 \mu \mathrm{L}$ of DAPI solution containing 
$1 \mu \mathrm{g} / \mathrm{mL}$ of DAPI in $0.1 \%$ Triton X-100 in PBS and analyzed them by flow cytometry on an LSR II flow cytometer (BD Biosciences, San Jose, CA, USA). DAPI was excited at $345 \mathrm{~nm}$ and its emission was detected at 458 $\mathrm{nm}$. Alexa Fluor 488 was excited at $494 \mathrm{~nm}$ and its emission was detected at $519 \mathrm{~nm}$.

Statistical significance of the changes was determined using a Dirichlet likelihood ratio test that is similar to a $\chi 2$ test of independence. To summarize, the cell cycle phase proportions at each timepoint for each microRNA transfection were fit to a maximum likelihood Dirichlet distribution by an iterated, alternating mean/precision estimation method [113]. The distributions and their log likelihoods were calculated for the null hypothesis of identical Dirichlet distributions and the alternative hypothesis of two different Dirichlet distributions for the negative control transfection and the microRNA transfection of interest. The log likelihoods of the two hypotheses were compared using the test statistic

$$
D=-2 \log L\left(H_{o} \mid C\right)+2 \log L\left(H_{a} \mid C\right),
$$

where $C$ is the flow cytometry data at the particular timepoint. $D$ was then evaluated on the $\chi 2$ distribution for three degrees of freedom to calculate a $P$ value (the alternative hypothesis calculates two three-parameter Dirichlet distributions instead of one).

\section{Cell size and number analysis}

Dermal fibroblasts were trypsinized and resuspended in PBS, and cell size was measured in triplicate for each sample using the Beckman Coulter counter. Cell numbers were determined using the Countess automated cell counter (Invitrogen). For $m i R-29$ transfection, cell numbers were evaluated using a one-sided $t$ test.

\section{Immunoblotting for miR-29 targets}

Fibroblasts were reverse transfected with $m i R-29 b$ or a negative control microRNA as above, but cells were plated at either 7,500 cells $/ \mathrm{cm}^{2}$ (proliferating and mitogen-starved conditions) or 750,000 cells $/ \mathrm{cm}^{2}$ (contact-inhibited condition). Twenty-four hours post transfection, cells were washed with warm PBS and then switched to low-serum conditions for collecting extracellular matrix proteins: FBM (Lonza), insulin (Lonza), and 0.1\% FBS (v/v). Proliferating and contact-inhibited conditions were additionally supplemented with $30 \mathrm{ng} / \mathrm{mL}$ recombinant human PDGF-BB.

After culturing for 4 days in low-serum medium, intracellular proteins were collected by washing cells in ice-cold PBS followed by scraping cells into a solution of 4\% SDS, $100 \mathrm{mM}$ Tris- $\mathrm{HCl} \mathrm{pH} \mathrm{7.5,} 1 \mathrm{mM} \mathrm{DTT}$, and an EDTA-free protease inhibitor cocktail (Roche). Lysates were vortexed, heated briefly $\left(5-10 \mathrm{~min}\right.$ at $\left.95^{\circ} \mathrm{C}\right)$, sonicated until the solutions became non-viscous, and then centrifuged at $10,000 \times \mathrm{g}$ for $10 \mathrm{~min}$. The soluble lysates were transferred to new tubes and insoluble pellets were discarded. Determination of soluble lysate concentration and immunoblotting conditions were otherwise identical to those previously described in Lemons et al. and Pollina et al. [52,54]. Antibodies and specific blotting conditions used are described below.

\section{TGF- $\beta$ treatment and signaling analysis}

Cells were treated with recombinant human TGF-ß1 (Life Technologies) for $48 \mathrm{~h}$ in low-serum medium: high glucose DMEM with $4.5 \mathrm{mM}$ glutamine, serum replacement (Sigma-Aldrich, S2640), and $30 \mathrm{ng} / \mathrm{mL}$ PDGF-BB. Cells were lysed in TRIzol, and RNA was harvested with the Direct-zol RNA Miniprep Kit (Zymo Research). The expression of $m i R-29 b$ was measured in cell samples on a small scale normalized to $m i R-100$ using the miRCURY LNA Universal RT microRNA PCR kit (Exiqon) with miR$29 b$ and $m i R-100$ primer sets and an ABI 7900 real-time PCR system. Total RNA samples were extracted using TRIzol reagent (Life Technologies) along with the Directzol RNA Miniprep kit (Zymo Research). Relative expression changes were quantified in triplicate using the $\Delta \Delta C_{t}$ method on SYBR green fluorescence. Cell lysates from proliferating, 4 days serum-starved, and 7 days contactinhibited fibroblasts were harvested according to the procedures above.

\section{Antibodies}

The following primary antibodies were used for immunoblotting: rabbit polyclonal IgG against collagen I (Calbiochem, 234167), rabbit polyclonal IgG against COL3A1 (Santa Cruz Biotechnology, sc-28888), biotinylated rabbit polyclonal IgG against Collagen VI (Acris Antibodies, R1043B), rabbit monoclonal IgG against Phospho-Smad3 Ser423/425 (Cell Signaling Technology, 9520), rabbit monoclonal IgG against $\alpha$-Tubulin (Cell Signaling Technology, 2125), and rabbit polyclonal IgG against GAPDH (Abcam, ab9485). Each antibody was diluted in Tris-buffered saline containing $0.1 \%$ Tween-20 and 5\% BSA and incubated with immunoblot membranes overnight at $4^{\circ} \mathrm{C}$.

\section{Accession numbers}

The microarray data generated for this study (the microRNA microarrays and the miR-29 overexpression microarrays) have been deposited in the NCBI Gene Expression Omnibus (GEO) [114] as one SuperSeries under the accession number GSE42614. Serum starvation/restimulation timecourse microarrays [54] and contact inhibition microarrays [52] were published in prior studies and are available in GEO with accessions GSE42681 and GSE42612, respectively. 


\section{Additional material}

Additional file 1: Contains additional tables and figures referred to in the text.

\section{Abbreviations}

$\mathrm{Cl}$ : confidence interval or contact inhibition; EdU: 5-ethynyl-2'-deoxyuridine; FDR: false discovery rate; qRT-PCR: quantitative reverse-transcription polymerase chain reaction; SS: serum starvation.

\section{Authors' contributions}

EJS, ALM, and JL conducted microarray experiments. EJS performed the statistical analyses and biochemical studies. EJ, MK, ALM, EJS, and MR conducted the molecular biology assays. ESS, TC, EJS, and MR conducted the cell cycle assays. EJS, ALM, JF, and HC conceived of the study, participated in its design and coordination, and helped to draft the manuscript. All authors read and approved the final manuscript.

\section{Competing interests}

The authors declare that they have no competing interests.

\section{Acknowledgements}

$\mathrm{HC}$ is the Milton E. Cassel scholar of the Rita Allen Foundation. EJS and EJ are supported in part by a National Science Foundation Graduate Research Fellowship DGE-0646086. HC and ALM are supported by the NIGMS Center of Excellence grant P50 GM071508. ALM acknowledges support from National Cancer Institute K01CA128887. EJ acknowledges support from NIH Training Grant 2T32 CA009528. JF acknowledges support from $\mathrm{NCl}$ training grant 5T32 CA009528. TC and MK acknowledge support from the Howard Hughes Medical Institute/Princeton Summer Undergraduate Research Program. JL acknowledges support from NIH training grant T32 HG003284. This work was funded by PhRMA Foundation grant 2007RSG19572, NIH/ NIGMS 1R01 GM081686, and NIH/NIGMS 1R01 GM086465.

We wish to acknowledge Sarah Pfau (MIT), Cheng Shi (Princeton University), Liling Wang (Princeton University), Christina deCoste (Princeton University), Nithya Krishnan (Princeton University), Irene Raitman (Princeton University), Rosetta Inpharmatics, and all of the members of the Coller lab for helpful discussions. PUMAdb is funded in part by the National Institute of General Medical Sciences (NIGMS) (NIH grant P50 GM071508).

Received: 9 July 2012 Revised: 5 December 2012

Accepted: 22 December 2012 Published: 22 December 2012

\section{References}

1. Pardee $A B$ : A restriction point for control of normal animal cell proliferation. Proc Natl Acad Sci USA 1974, 71:1286-1290.

2. Coller HA, Sang L, Roberts JM: A new description of cellular quiescence. PLoS Biology 2006, 4:e83.

3. Coppock DL, Kopman C, Scandalis S, Gilleran S: Preferential gene expression in quiescent human lung fibroblasts. Cell Growth Differ 1993, 4:483-493.

4. Iyer VR, Eisen MB, Ross DT, Schuler G, Moore T, Lee JC, Trent JM, Staudt LM Hudson J Jr, Boguski MS, Lashkari D, Shalon D, Botstein D, Brown PO: The transcriptional program in the response of human fibroblasts to serum Science 1999, 283:83-87.

5. Liu H, Adler AS, Segal E, Chang HY: A transcriptional program mediating entry into cellular quiescence. PLoS Genet 2007, 3:e91.

6. Schneider C, King RM, Philipson L: Genes specifically expressed at growth arrest of mammalian cells. Cell 1988, 54:787-793.

7. Teague TK, Hildeman D, Kedl RM, Mitchell T, Rees W, Schaefer BC, Bender J, Kappler J, Marrack P: Activation changes the spectrum but not the diversity of genes expressed by T cells. Proc Natl Acad Sci USA 1999, 96:12691-12696.

8. Glynne R, Ghandour G, Rayner J, Mack DH, Goodnow CC: B-lymphocyte quiescence, tolerance and activation as viewed by global gene expression profiling on microarrays. Immunol Rev 2000, 176:216-246.

9. Venezia TA, Merchant AA, Ramos CA, Whitehouse NL, Young AS, Shaw CA, Goodell MA: Molecular signatures of proliferation and quiescence in hematopoietic stem cells. PLoS Biol 2004, 2:e301.
10. Litovchick L, Florens LA, Swanson SK, Washburn MP, DeCaprio JA: DYRK1A protein kinase promotes quiescence and senescence through DREAM complex assembly. Genes Dev 2011, 25:801-813.

11. Litovchick L, Sadasivam S, Florens L, Zhu X, Swanson SK, Velmurugan S, Chen R, Washburn MP, Liu XS, DeCaprio JA: Evolutionarily conserved multisubunit RBL2/p130 and E2F4 protein complex represses human cell cycle-dependent genes in quiescence. Mol Cell 2007, 26:539-551.

12. Perna D, Faga G, Verrecchia A, Gorski MM, Barozzi I, Narang V, Khng J, Lim KC, Sung WK, Sanges R, Stupka E, Oskarsson T, Trumpp A, Wei CL, Muller H, Amati B: Genome-wide mapping of Myc binding and gene regulation in serum-stimulated fibroblasts. Oncogene 2012, 31:1695-1709.

13. Grandori C, Cowley SM, James LP, Eisenman RN: The Myc/Max/Mad network and the transcriptional control of cell behavior. Annu Rev Cell Dev Biol 2000, 16:653-699.

14. Sang L, Coller HA, Roberts JM: Control of the reversibility of cellular quiescence by the transcriptional repressor HES1. Science 2008, 321:1095-1100.

15. Essers MA, Weijzen S, de Vries-Smits AM, Saarloos I, de Ruiter ND, Bos JL, Burgering BM: FOXO transcription factor activation by oxidative stress mediated by the small GTPase Ral and JNK. EMBO J 2004, 23:4802-4812.

16. Skon CN, Jameson SC: Fox factors fight over T cell quiescence. Nat Immunol 2011, 12:522-524.

17. Filipowicz W, Bhattacharyya SN, Sonenberg N: Mechanisms of posttranscriptional regulation by microRNAs: are the answers in sight?. Nat Rev Genet 2008, 9:102-114.

18. Wu L, Fan J, Belasco JG: MicroRNAs direct rapid deadenylation of mRNA Proc Natl Acad Sci USA 2006, 103:4034-4039.

19. Flynt $A S$, Lai EC: Biological principles of microRNA-mediated regulation: shared themes amid diversity. Nat Rev Genet 2008, 9:831-842.

20. Bartel DP: MicroRNAs: genomics, biogenesis, mechanism, and function. Cell 2004, 116:281-297.

21. Medina R, Zaidi SK, Liu CG, Stein JL, van Wijnen AJ, Croce CM, Stein GS: MicroRNAs 221 and 222 bypass quiescence and compromise cell survival. Cancer Res 2008, 68:2773-2780.

22. Gillies JK, Lorimer IA: Regulation of p27Kip1 by miRNA 221/222 in glioblastoma. Cell Cycle 2007, 6:2005-2009.

23. le Sage C, Nagel R, Egan DA, Schrier M, Mesman E, Mangiola A, Anile C, Maira G, Mercatelli N, Ciafre SA, Farace MG, Agami R: Regulation of the p27(Kip1) tumor suppressor by miR-221 and miR-222 promotes cancer cell proliferation. EMBO J 2007, 26:3699-3708.

24. Galardi S, Mercatelli N, Giorda E, Massalini S, Frajese GV, Ciafre SA Farace MG: miR-221 and miR-222 expression affects the proliferation potential of human prostate carcinoma cell lines by targeting p27Kip1. J Biol Chem 2007, 282:23716-23724.

25. Visone R, Russo L, Pallante P, De Martino I, Ferraro A, Leone V, Borbone E, Petrocca F, Alder H, Croce CM, Fusco A: MicroRNAs (miR)-221 and miR222 , both overexpressed in human thyroid papillary carcinomas, regulate p27Kip1 protein levels and cell cycle. Endocr Relat Cancer 2007, 14:791-798.

26. Nimmo RA, Slack FJ: An elegant miRror: microRNAs in stem cells, developmental timing and cancer. Chromosoma 2009, 118:405-418.

27. Moss EG: Heterochronic genes and the nature of developmental time. Curr Biol 2007, 17:R425-434

28. Yu F, Yao H, Zhu P, Zhang X, Pan O, Gong C, Huang Y, Hu X, Su F, Lieberman J, Song E: let-7 regulates self renewal and tumorigenicity of breast cancer cells. Cell 2007, 131:1109-1123.

29. Caygill $E E$, Johnston $L A$ : Temporal regulation of metamorphic processes in Drosophila by the let-7 and miR-125 heterochronic microRNAs. Curr Biol 2008, 18:943-950.

30. Reinhart BJ, Slack FJ, Basson M, Pasquinelli AE, Bettinger JC, Rougvie AE, Horvitz HR, Ruvkun G: The 21-nucleotide let-7 RNA regulates developmental timing in Caenorhabditis elegans. Nature 2000, 403:901-906.

31. Ambros V: MicroRNAs and developmental timing. Curr Opin Genet Dev 2011, 21:511-517.

32. Lee YS, Kim HK, Chung S, Kim KS, Dutta A: Depletion of human micro-RNA miR-125b reveals that it is critical for the proliferation of differentiated cells but not for the down-regulation of putative targets during differentiation. J Biol Chem 2005, 280:16635-16641.

33. Schulman BR, Esquela-Kerscher A, Slack FJ: Reciprocal expression of lin-4 and the microRNAs let-7 and mir-125 during mouse embryogenesis. Dev Dyn 2005, 234:1046-1054. 
34. Boyerinas B, Park SM, Hau A, Murmann AE, Peter ME: The role of let-7 in cell differentiation and cancer. Endocr Relat Cancer 2010, 17:F19-36.

35. Johnson CD, Esquela-Kerscher A, Stefani G, Byrom M, Kelnar K, Ovcharenko D, Wilson M, Wang X, Shelton J, Shingara J, Chin L, Brown D, Slack FJ: The let-7 microRNA represses cell proliferation pathways in human cells. Cancer Res 2007, 67:7713-7722.

36. Legesse-Miller A, Elemento O, Pfau S, Forman J, Tavazoie S, Coller H: let-7 overexpression leads to an increased fraction of cells in $\mathrm{G} 2 / \mathrm{M}$, direct down-regulation of $\mathrm{Cdc} 34$ and stabilization of Wee1 kinase in primary fibroblasts. J Biol Chem 2009, 284:6605-6609.

37. Sokol NS, Xu P, Jan Y-N, Ambros V: Drosophila let-7 microRNA is required for remodeling of the neuromusculature during metamorphosis. Genes Dev 2008, 22:1591-1596.

38. Esquela-Kerscher A, Trang P, Wiggins JF, Patrawala L, Cheng A, Ford L, Weidhaas JB, Brown D, Bader AG, Slack FJ: The let-7 microRNA reduces tumor growth in mouse models of lung cancer. Cell Cycle 2008, 7:759-764.

39. Johnson SM, Grosshans H, Shingara J, Byrom M, Jarvis R, Cheng A, Labourier $\mathrm{E}$, Reinert $\mathrm{KL}$, Brown D, Slack FJ: RAS is regulated by the let-7 microRNA family. Cell 2005, 120:635-647.

40. Kumar MS, Erkeland SJ, Pester RE, Chen CY, Ebert MS, Sharp PA, Jacks T: Suppression of non-small cell lung tumor development by the let-7 microRNA family. Proc Natl Acad Sci USA 2008, 105:3903-3908.

41. Lee YS, Dutta A: The tumor suppressor microRNA let-7 represses the HMGA2 oncogene. Genes Dev 2007, 21:1025-1030

42. Takamizawa J, Konishi $H$, Yanagisawa $K$, Tomida S, Osada $H$, Endoh $H_{1}$ Harano T, Yatabe Y, Nagino M, Nimura Y, Mitsudomi T, Takahashi T: Reduced expression of the let-7 microRNAs in human lung cancers in association with shortened postoperative survival. Cancer Res 2004, 64:3753-3756.

43. Sampson VB, Rong NH, Han J, Yang Q, Aris V, Soteropoulos P, Petrelli NJ, Dunn SP, Krueger LJ: MicroRNA let-7a down-regulates MYC and reverts MYC-induced growth in Burkitt lymphoma cells. Cancer Res 2007, 67:9762-9770.

44. Trang P, Wiggins JF, Daige $C L$, Cho C, Omotola M, Brown D, Weidhaas JB, Bader AG, Slack FJ: Systemic delivery of tumor suppressor microRNA mimics using a neutral lipid emulsion inhibits lung tumors in mice. Mol Ther 2011, 19:1116-1122.

45. Trang P, Medina PP, Wiggins JF, Ruffino L, Kelnar K, Omotola M, Homer R, Brown D, Bader AG, Weidhaas JB, Slack FJ: Regression of murine lung tumors by the let-7 microRNA. Oncogene 2010, 29:1580-1587.

46. O'Donnell KA, Wentzel EA, Zeller Kl, Dang CV, Mendell JT: c-Myc-regulated microRNAs modulate E2F1 expression. Nature 2005, 435:839-843.

47. He L, Thomson JM, Hemann MT, Hernando-Monge E, Mu D, Goodson S, Powers S, Cordon-Cardo C, Lowe SW, Hannon GJ, Hammond SM: A microRNA polycistron as a potential human oncogene. Nature 2005 435:828-833.

48. Coller HA, Forman JJ, Legesse-Miller A: "Myc'ed messages": myc induces transcription of E2F1 while inhibiting its translation via a microRNA polycistron. PLOS Genet 2007, 3:e146.

49. Sylvestre Y, De Guire V, Querido E, Mukhopadhyay UK, Bourdeau V, Major F, Ferbeyre G, Chartrand P: An E2F/miR-20a autoregulatory feedback loop. J Biol Chem 2007, 282:2135-2143.

50. Li Y, Zhang H, Chen Y: MicroRNA-mediated positive feedback loop and optimized bistable switch in a cancer network involving miR-17-92. PloS One 2011, 6:e26302.

51. Aguda BD, Kim Y, Piper-Hunter MG, Friedman A, Marsh CB: MicroRNA regulation of a cancer network: consequences of the feedback loops involving miR-17-92, E2F, and Myc. Proc Natl Acad Sci USA 2008, 105:19678-19683.

52. Lemons JMS, Feng X-J, Bennett BD, Legesse-Miller A, Johnson EL, Raitman I, Pollina EA, Rabitz HA, Rabinowitz JD, Coller HA: Quiescent fibroblasts exhibit high metabolic activity. PLoS Biology 2010, 8:e1000514.

53. Raymond CK, Roberts BS, Garrett-Engele P, Lim LP, Johnson JM: Simple, quantitative primer-extension PCR assay for direct monitoring of microRNAs and short-interfering RNAs. RNA 2005, 11:1737-1744.

54. Pollina EA, Legesse-Miller A, Haley EM, Goodpaster T, RandolphHabecker J, Coller HA: Regulating the angiogenic balance in tissues: a potential role for the proliferative state of fibroblasts. Cell Cycle 2008, 7:2056-2070

55. Friedman RC, Farh KK-H, Burge CB, Bartel DP: Most mammalian mRNAs are conserved targets of microRNAs. Genome Res 2009, 19:92-105.
56. Grimson A, Farh KK-H, Johnston WK, Garrett-Engele P, Lim LP, Bartel DP: MicroRNA targeting specificity in mammals: determinants beyond seed pairing. Mol Cell 2007, 27:91-105.

57. Jacobsen A, Wen J, Marks DS, Krogh A: Signatures of RNA binding proteins globally coupled to effective microRNA target sites. Genome Res 2010, 20:1010-1019.

58. Didiano D, Hobert O: Molecular architecture of a miRNA-regulated 3'-UTR. RNA 2008, 14:1297-1317

59. Nolde MJ, Saka N, Reinert KL, Slack FJ: The Caenorhabditis elegans pumilio homolog, puf- 9 , is required for the $3^{\prime} U T R$-mediated repression of the let-7 microRNA target gene, hbl-1. Dev Biol 2007, 305:551-563.

60. Engels B, Jannot G, Remenyi J, Simard MJ, Hutvagner G: Polypyrimidine tract binding protein (hnRNP I) is possibly a conserved modulator of miRNA-mediated gene regulation. PloS One 2012, 7:e33144.

61. Sandberg R, Neilson JR, Sarma A, Sharp PA, Burge CB: Proliferating cells express mRNAs with shortened $3^{\prime}$ untranslated regions and fewer microRNA target sites. Science 2008, 320:1643-1647.

62. Mayr C, Bartel DP: Widespread shortening of $3^{\prime}$ UTRs by alternative cleavage and polyadenylation activates oncogenes in cancer cells. Cell 2009, 138:673-684

63. Ji Z, Lee JY, Pan Z, Jiang B, Tian B: Progressive lengthening of $3^{\prime}$ untranslated regions of mRNAs by alternative polyadenylation during mouse embryonic development. Proc Natl Acad Sci USA 2009, 106:7028-7033.

64. Arvey A, Larsson E, Sander C, Leslie CS, Marks DS: Target mRNA abundance dilutes microRNA and siRNA activity. Mol Syst Biol 2010, 6:363.

65. Smibert P, Miura P, Westholm JO, Shenker S, May G, Duff MO, Zhang D, Eads BD, Carlson J, Brown JB, Eisman RC, Andrews J, Kaufman T, Cherbas P, Celniker SE, Graveley BR, Lai EC: Global patterns of tissue-specific alternative polyadenylation in Drosophila. Cell Rep 2012, 1:277-289.

66. Larsson E, Sander C, Marks D: mRNA turnover rate limits siRNA and microRNA efficacy. Mol Syst Biol 2010, 6:433.

67. Luna C, Li G, Qiu J, Epstein DL, Gonzalez P: Role of miR-29b on the regulation of the extracellular matrix in human trabecular meshwork cells under chronic oxidative stress. Mol Vis 2009, 15:2488-2497.

68. Maurer B, Stanczyk J, Jüngel A, Akhmetshina A, Trenkmann M, Brock M, Kowal-Bielecka O, Gay RE, Michel BA, Distler JH, Gay S, Distler O: miR-29 is a key regulator of collagen expression in systemic sclerosis. Arthritis Rheum 2010, 62:1733-1743.

69. Villarreal G Jr, Oh DJ, Kang MH, Rhee DJ: Coordinated regulation of extracellular matrix synthesis by the microRNA-29 family in the trabecular meshwork. Invest Ophthalmol Vis Sci 2011, 52:3391-3397.

70. Kriegel AJ, Liu Y, Fang Y, Ding X, Liang M: The miR-29 family: genomics, cell biology, and relevance to renal and cardiovascular injury. Physiol Genomics 2012, 44:237-244.

71. Merk DR, Chin JT, Dake BA, Maegdefessel L, Miller MO, Kimura N, Tsao PS, losef C, Berry GJ, Mohr FW, Spin JM, Alvira CM, Robbins RC, Fischbein MP: miR-29b participates in early aneurysm development in Marfan syndrome. Circ Res 2012, 110:312-324

72. Xiao J, Meng XM, Huang XR, Chung AC, Feng YL, Hui DS, Yu CM, Sung Ju, Lan HY: miR-29 inhibits bleomycin-induced pulmonary fibrosis in mice. Mol Ther 2012, 20:1251-1260.

73. Sporn MB, Roberts AB, Shull JH, Smith JM, Ward JM, Sodek J: Polypeptide transforming growth factors isolated from bovine sources and used for wound healing in vivo. Science 1983, 219:1329-1331.

74. Bandyopadhyay S, Friedman RC, Marquez RT, Keck K, Kong B, Icardi MS, Brown KE, Burge CB, Schmidt WN, Wang Y, McCaffrey AP: Hepatitis C virus infection and hepatic stellate cell activation downregulate miR-29: miR29 overexpression reduces hepatitis $C$ viral abundance in culture. J Infect Dis 2011, 203:1753-1762.

75. Luna C, Li G, Qiu J, Epstein DL, Gonzalez P: Cross-talk between miR-29 and transforming growth factor-betas in trabecular meshwork cells. Invest Ophthalmol Vis Sci 2011, 52:3567-3572.

76. Ghosh AK, Yuan W, Mori Y, Varga J: Smad-dependent stimulation of type I collagen gene expression in human skin fibroblasts by TGF-beta involves functional cooperation with p300/CBP transcriptional coactivators. Oncogene 2000, 19:3546-3555.

77. Cutroneo KR: How is Type I procollagen synthesis regulated at the gene level during tissue fibrosis. J Cell Biochem 2003, 90:1-5

78. Salic A, Mitchison TJ: A chemical method for fast and sensitive detection of DNA synthesis in vivo. Proc Natl Acad Sci USA 2008, 105:2415-2420. 
79. Mollinari C, Reynaud C, Martineau-Thuillier S, Monier S, Kieffer S, Garin J, Andreassen PR, Boulet A, Goud B, Kleman JP, Margolis RL: The mammalian passenger protein TD-60 is an RCC1 family member with an essential role in prometaphase to metaphase progression. Dev Cell 2003, 5:295-307.

80. Hertel J, Bartschat S, Wintsche A, Otto C, Of The Bioinformatics Computer Lab TS, Stadler PF: Evolution of the let-7 microRNA Family. RNA Biol 2012, 9.

81. Pasquinelli AE, Reinhart BJ, Slack F, Martindale MQ, Kuroda MI, Maller B, Hayward DC, Ball EE, Degnan B, Muller P, Spring J, Srinivasan A, Fishman M, Finnerty J, Corbo J, Levine M, Leahy P, Davidson E, Ruvkun G: Conservation of the sequence and temporal expression of let-7 heterochronic regulatory RNA. Nature 2000, 408:86-89.

82. Sempere LF, Dubrovsky EB, Dubrovskaya VA, Berger EM, Ambros V: The expression of the let-7 small regulatory RNA is controlled by ecdysone during metamorphosis in Drosophila melanogaster. Dev Biol 2002, 244:170-179.

83. Bashirullah A, Pasquinelli AE, Kiger AA, Perrimon N, Ruvkun G, Thummel CS: Coordinate regulation of small temporal RNAs at the onset of Drosophila metamorphosis. Dev Biol 2003, 259:1-8.

84. Hutvagner G, McLachlan J, Pasquinelli AE, Balint E, Tuschl T, Zamore PD: A cellular function for the RNA-interference enzyme Dicer in the maturation of the let-7 small temporal RNA. Science 2001, 293:834-838.

85. Lagos-Quintana M, Rauhut R, Yalcin A, Meyer J, Lendeckel W, Tuschl T: Identification of tissue-specific microRNAs from mouse. Curr Biol 2002, 12:735-739.

86. Sempere LF, Freemantle S, Pitha-Rowe I, Moss E, Dmitrovsky E, Ambros V: Expression profiling of mammalian microRNAs uncovers a subset of brain-expressed microRNAs with possible roles in murine and human neuronal differentiation. Genome Biol 2004, 5:R13.

87. Lu J, Getz G, Miska EA, Alvarez-Saavedra E, Lamb J, Peck D, SweetCordero A, Ebert BL, Mak RH, Ferrando AA, Downing JR, Jacks T, Horvitz HR, Golub TR: MicroRNA expression profiles classify human cancers. Nature 2005, 435:834-838

88. Raponi M, Dossey L, Jatkoe T, Wu X, Chen G, Fan H, Beer DG: MicroRNA classifiers for predicting prognosis of squamous cell lung cancer. Cancer Res 2009, 69:5776-5783.

89. Peter ME: Let-7 and miR-200 microRNAs: guardians against pluripotency and cancer progression. Cell Cycle 2009, 8:843-852.

90. Mitra D, Das PM, Huynh FC, Jones FE: Jumonji/ARID1 B (JARID1B) protein promotes breast tumor cell cycle progression through epigenetic repression of microRNA let-7e. J Biol Chem 2011, 286:40531-40535.

91. Guan Y, Yao H, Zheng Z, Qiu G, Sun K: MiR-125b targets BCL3 and suppresses ovarian cancer proliferation. Int J Cancer 2011, 128:2274-2283.

92. Zhang Y, Yan LX, Wu QN, Du ZM, Chen J, Liao DZ, Huang MY, Hou JH, Wu QL, Zeng MS, Huang WL, Zeng YX, Shao JY: miR-125b is methylated and functions as a tumor suppressor by regulating the ETS1 protooncogene in human invasive breast cancer. Cancer Res 2011, 71:3552-3562

93. Morita K, Han M: Multiple mechanisms are involved in regulating the expression of the developmental timing regulator lin-28 in Caenorhabditis elegans. EMBO J 2006, 25:5794-5804

94. Wu L, Belasco JG: Micro-RNA regulation of the mammalian lin-28 gene during neuronal differentiation of embryonal carcinoma cells. Mol Cell Biol 2005, 25:9198-9208.

95. Li Z, Hassan MQ, Jafferji M, Ageilan Rl, Garzon R, Croce CM, van Wijnen AJ, Stein JL, Stein GS, Lian JB: Biological functions of miR-29b contribute to positive regulation of osteoblast differentiation. J Biol Chem 2009, 284:15676-15684.

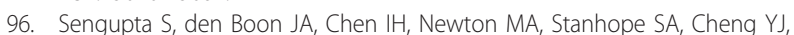
Chen CJ, Hildesheim A, Sugden B, Ahlquist P: MicroRNA 29c is downregulated in nasopharyngeal carcinomas, up-regulating mRNAs encoding extracellular matrix proteins. Proc Natl Acad Sci USA 2008, 105:5874-5878.

97. Steele R, Mott JL, Ray RB: MBP-1 upregulates miR-29b that represses Mcl-1, collagens, and matrix-metalloproteinase- 2 in prostate cancer cells. Genes Cancer 2010, 1:381-387.

98. Renault VM, Rafalski VA, Morgan AA, Salih DA, Brett JO, Webb AE, Villeda SA, Thekkat PU, Guillerey C, Denko NC, Palmer TD, Butte AJ, Brunet A: FoxO3 regulates neural stem cell homeostasis. Cell Stem Cell 2009, 5:527-539.

99. Miyamoto K, Araki KY, Naka K, Arai F, Takubo K, Yamazaki S, Matsuoka S, Miyamoto T, Ito K, Ohmura M, Chen C, Hosokawa K, Nakauchi H,
Nakayama K, Nakayama Kl, Harada M, Motoyama N, Suda T, Hirao A: Foxo3a is essential for maintenance of the hematopoietic stem cell pool. Cell Stem Cell 2007, 1:101-112.

100. Tothova Z, Kollipara R, Huntly BJ, Lee BH, Castrillon DH, Cullen DE, McDowell EP, Lazo-Kallanian S, Williams IR, Sears C, Armstrong SA Passegue E, DePinho RA, Gilliland DG: FoxOs are critical mediators of hematopoietic stem cell resistance to physiologic oxidative stress. Cell 2007, 128:325-339.

101. Feng X, Ippolito GC, Tian L, Wiehagen K, Oh S, Sambandam A, Willen J, Bunte RM, Maika SD, Harriss JV, Caton AJ, Bhandoola A, Tucker PW, Hu H: Foxp1 is an essential transcriptional regulator for the generation of quiescent naive T cells during thymocyte development. Blood 2010, 115:510-518.

102. Feng $X$, Wang $H$, Takata H, Day TJ, Willen J, Hu H: Transcription factor Foxp1 exerts essential cell-intrinsic regulation of the quiescence of naive T cells. Nat Immunol 2011, 12:544-550.

103. Mott $J$, Kurita S, Cazanave SC, Bronk SF, Werneburg NW, FernandezZapico ME: Transcriptional suppression of mir-29b-1/mir-29a promoter by c-Myc, hedgehog, and NF-kappaB. J Cell Biochem 2010, 110:1155-1164.

104. Fabbri M, Garzon R, Cimmino A, Liu Z, Zanesi N, Callegari E, Liu S, Alder H, Costinean S, Fernandez-Cymering C, Volinia S, Guler G, Morrison CD, Chan KK, Marcucci G, Calin GA, Huebner K, Croce CM: MicroRNA-29 family reverts aberrant methylation in lung cancer by targeting DNA methyltransferases 3A and 3B. Proc Natl Acad Sci USA 2007, 104:15805-15810.

105. Mott JL, Kobayashi S, Bronk SF, Gores GJ: mir-29 regulates Mcl-1 protein expression and apoptosis. Oncogene 2007, 26:6133-6140.

106. Martinez I, Cazalla D, Almstead LL, Steitz JA, DiMaio D: miR-29 and miR-30 regulate B-Myb expression during cellular senescence. Proc Natl Acad Sci USA 2011, 108:522-527.

107. Santanam U, Zanesi N, Efanov A, Costinean S, Palamarchuk A, Hagan JP, Volinia S, Alder H, Rassenti L, Kipps T, Croce CM, Pekarsky Y: Chronic lymphocytic leukemia modeled in mouse by targeted miR-29 expression. Proc Natl Acad Sci USA 2010, 107:12210-12215.

108. King TE Jr, Pardo A, Selman M: Idiopathic pulmonary fibrosis. Lancet 2011, 378:1949-1961.

109. Gharaee-Kermani M, Hu B, Phan SH, Gyetko MR: Recent advances in molecular targets and treatment of idiopathic pulmonary fibrosis: focus on TGFbeta signaling and the myofibroblast. Curr Med Chem 2009, 16:1400-1417.

110. Leek JT, Storey JD: Capturing heterogeneity in gene expression studies by surrogate variable analysis. PLoS Genetics 2007, 3:1724-1735.

111. Generic Gene Ontology Term Finder. [http://go.princeton.edu/cgi-bin/ GOTermFinder].

112. TargetScan 5.1. [www.targetscan.org].

113. Minka TP: Estimating a Dirichlet distribution. Microsoft Research; 2000.

114. Edgar R, Domrachev M, Lash AE: Gene Expression Omnibus: NCBI gene expression and hybridization array data repository. Nucleic Acids Res 2002, 30:207-210.

doi:

Cite this article as: Suh et al:: A microRNA network regulates proliferative timing and extracellular matrix synthesis during cellular quiescence in fibroblasts. Genome Biology 2012 13:R121.

\section{Submit your next manuscript to BioMed Central and take full advantage of:}

- Convenient online submission

- Thorough peer review

- No space constraints or color figure charges

- Immediate publication on acceptance

- Inclusion in PubMed, CAS, Scopus and Google Scholar

- Research which is freely available for redistribution 